\title{
Observing and Modeling the Vertical Wind Profile at Multiple Sites in and above the Amazon Rain Forest Canopy
}

\author{
Raoni Aquino Silva de Santana, ${ }^{1}$ Cléo Quaresma Dias-Júnior, \\ Roseilson Souza do Vale, ${ }^{1}$ Júlio Tóta, ${ }^{1}$ and David Roy Fitzjarrald ${ }^{3}$ \\ ${ }^{1}$ Federal University of Western Pará (UFOPA), Santarém, PA, Brazil \\ ${ }^{2}$ Federal Institute of Pará (IFPA) Bragança, PA, Brazil \\ ${ }^{3}$ University at Albany, SUNY, Albany, NY, USA \\ Correspondence should be addressed to Raoni Aquino Silva de Santana; raoniass@gmail.com
}

Received 4 September 2016; Revised 24 November 2016; Accepted 25 December 2016; Published 18 January 2017

Academic Editor: Enrico Ferrero

Copyright (C) 2017 Raoni Aquino Silva de Santana et al. This is an open access article distributed under the Creative Commons Attribution License, which permits unrestricted use, distribution, and reproduction in any medium, provided the original work is properly cited.

\begin{abstract}
We analyzed the vertical wind profile measured at six experimental tower sites in dense forest in the Amazon Basin and examined how well two simple models can reproduce these observations. In general, the vertical wind profile below the canopy is strongly affected by the forest structure. From the forest floor to $0.65 h$ (where $h=35 \mathrm{~m}$ is the average height of the forest canopy for sites considered), the wind profile is approximately constant with height with speeds less than $1 \mathrm{~ms}^{-1}$. Above 0.65 to $2.25 h$, the wind speed increases with height. Testing these data with the Yi and Souza models showed that each was able to reproduce satisfactorily the vertical wind profile for different experimental sites in the Amazon. Using the Souza Model, it was possible to use fewer input variables necessary to simulate the profile.
\end{abstract}

\section{Introduction}

There are several issues that have motivated researchers to intensify their studies on the interaction between the Amazon rainforest and the atmosphere [1-4]. Among these issues is the role that the Amazonian forest exerts the liberation of energy in the tropical atmosphere [5], on the hydrological cycle [6], and in the global balance of secondary gaseous components in the atmosphere, such as ozone, carbon dioxide, and hydrocarbons [7]. Furthermore, there are problems associated with deforestation in the Amazon that could have a direct influence on global climate change [8]. In this context, understanding the processes of energy, mass, and momentum exchanges between the Amazon forest and the atmosphere is of fundamental importance. Although considerable progress has been made in this area over the past 30 years [9-12], more details on variables controlling the said exchanges are needed.

According to Yi [13], the vertical profile of the wind velocity, together with the Reynolds stress, is of fundamental importance to the characterization of turbulent flow over vegetated surfaces, an assertion particularly relevant in dense forest areas. Studies conducted in Amazon forests have shown persistent decoupling of the atmospheric flow between the lower and upper forest canopy [10], due to reduced penetration of direct solar radiation inside the forest and corresponding static stability near the forest floor [9], a condition that often persists over the entire diurnal cycle $[11,12,14,15]$. Mechanical turbulence generated at canopy top by the rough canopy becomes a determining factor that dominates turbulent mixing processes between the upper and lower forest canopy [16].

An hypothesized, dynamic instability associated with an inflection point in the above-canopy wind profile in what is known as the roughness sublayer [17-20] is another factor that may contribute to the production of turbulence that penetrates into the lower canopy [16, 21]. Dias Júnior et al. [22], working in the Amazon, showed the existence of a strong correlation between the inflection point height and time scales of coherent structures, known to contribute to turbulent mixing in forest areas [21]. 
TABLE 1: Instruments and data periods used.

\begin{tabular}{|c|c|c|c|c|c|}
\hline Experimental sites & Instruments & Reference & $\begin{array}{c}\text { Measurement } \\
\text { heights }\end{array}$ & Sampling rate & Measurement period \\
\hline K34 [4] & $\begin{array}{l}\text { 3D-sonic } \\
\text { anemometer }\end{array}$ & $\begin{array}{l}\text { CSAT3, Campbell } \\
\text { scientific }\end{array}$ & $\begin{array}{c}1.5,7.0,13.5,18.4 \\
22.1,24.5,31.6 \\
34.9,40.4,48.2\end{array}$ & $20 \mathrm{~Hz}$ & $\begin{array}{l}\text { June } 2014 \text { to January } \\
2015\end{array}$ \\
\hline Rebio-Jarú [22] & Cup anemometer & $\begin{array}{l}\text { Low Power A100L2, } \\
\text { Vector Instruments Inc. }\end{array}$ & $\begin{array}{l}55.0,50.55,47.7 \\
42.9,40.25,37.8 \\
32.8,26.65,14.30\end{array}$ & $0.1 \mathrm{~Hz}$ & February 1999 \\
\hline \multirow{4}{*}{ Santarém [30] } & Cup anemometer & $\begin{array}{l}\text { 5103, R.M. Young } \\
\text { Company }\end{array}$ & $64.1,52,38.2,30.7$ & $1 \mathrm{~Hz}$ & \multirow{4}{*}{ July to November 2013} \\
\hline & $\begin{array}{c}\text { 3D-sonic } \\
\text { anemometer }\end{array}$ & $\begin{array}{l}\text { CSAT, Campbell } \\
\text { scientific }\end{array}$ & 57.8 & $10 \mathrm{~Hz}$ & \\
\hline & $\begin{array}{l}\text { 2D-sonic } \\
\text { anemometer }\end{array}$ & $\begin{array}{l}\text { CATI/2, Applied } \\
\text { Technologies, Inc. }\end{array}$ & 1.8 & $1 \mathrm{~Hz}$ & \\
\hline & $\begin{array}{c}\text { 3D-sonic } \\
\text { anemometer }\end{array}$ & $\begin{array}{c}\text { ATI, Applied } \\
\text { Technologies, Inc. }\end{array}$ & 5 & $10 \mathrm{~Hz}$ & \\
\hline Caxiuanã [31] & sonic anemometers & $\begin{array}{l}\text { CSAT, Campbell } \\
\text { scientific }\end{array}$ & 57.8 & $10 \mathrm{~Hz}$ & April 18-24, 1999 \\
\hline \multirow{3}{*}{$\begin{array}{l}\text { ATTO - Triangular } \\
\text { tower [35] }\end{array}$} & $\begin{array}{c}\text { 3D-sonic } \\
\text { anemometer }\end{array}$ & $\begin{array}{l}\text { WindMaster, Gill } \\
\text { Instruments Ltd. }\end{array}$ & 78,41 e 30 & $10 \mathrm{~Hz}$ & \multirow{3}{*}{ February to April 2012} \\
\hline & $\begin{array}{l}\text { 2D-sonic } \\
\text { anemometer }\end{array}$ & $\begin{array}{l}\text { WindSonic, Gill } \\
\text { Instruments Ltd. }\end{array}$ & $23,36,45$ e 50 & $4 \mathrm{~Hz}$ & \\
\hline & $\begin{array}{c}\text { Automatic weather } \\
\text { station }\end{array}$ & $\begin{array}{c}\text { MetPak, Gill } \\
\text { Instruments Ltd. }\end{array}$ & 57,60 e 72 & $1 \mathrm{~Hz}$ & \\
\hline \multirow{2}{*}{ ATTO Square tower [3] } & $\begin{array}{c}\text { 3D-sonic } \\
\text { anemometer }\end{array}$ & R3, Gill Instruments Ltd. & 234080 & $10 \mathrm{~Hz}$ & \multirow[t]{2}{*}{ January to February 2012} \\
\hline & Cup anemometer & $\begin{array}{l}\text { 5103, R.M. Young } \\
\text { Company }\end{array}$ & $30,42,55$ & $1 \mathrm{~Hz}$ & \\
\hline
\end{tabular}

Only a few previous studies have been done using to describe the wind profile shape in the rain forest canopy, combining observational data and modeling. Sá and Pachêco [23], using a third-order polynomial fit, estimated the inflection point height and the average wind speed at the inflection point as well as a characteristic length scale used to normalize the vertical wind profile in an Amazonian forest. Souza et al. [24], using the same data as did Sá and Pachêco [23], proposed an empirical-analytic model that was able to satisfactorily reproduce the vertical wind profile observed.

What is common among most of the work on the vertical wind profile in the Amazon [22-25] is the use of data from a single point of measurements, with good spatial resolution for only part of the profile, raising the question that these studies may be unrepresentative of dense forest areas in the Amazon overall. Thus, the aim of this study was to evaluate the different aspects of the vertical wind profile measured at different experimental sites in the Amazon. In addition, simplified models were used to simulate the profiles. Furthermore, for one of these models, an improvement was proposed in its formulation in order to reduce the input variables necessary for the model to generate the wind profile.

\section{Materials and Methods}

2.1. Study Area and Data. This research used observational data collected in five experimental sites in the Brazilian
Amazon, where micrometeorological observation towers were installed, namely, the Rebio-Jarú Forest Reserve [28], located in the state of Rondonia in the Southwest Amazon; the Cuieiras Biological Reserve (also called site K34, [29]), located next to the city of Manaus, Amazonas; the Tapajós National Forest (FLONA, Km 67 site) near the city of Santarém, Pará [30]; the Caxiuanã National Forest about $350 \mathrm{~km}$ west of the city of Belém, Pará [31]; and the Uatumã Sustainable Development Reserve, in the ATTO site (Amazonian Tall Tower Observatory, [3]), city of Santo Antônio do Uatumã, Amazonas. For the latter experimental site, data from two measurements towers were used, which will be called triangular tower (TT) and square tower (ST). The experimental design of each site is summarized in Table 1 and the geographical position is shown in Figure 1. The data used in this work consists primarily of wind speed averages at different heights within and above the forest canopy at each experimental site, made by sonic (two- and threedimensional) and cup (specification of each instrument is listed in Table 1) anemometers.

Each of these experimental sites is in dense tropical forest with trees ranging from 30 to 40 meters high. The leaf area index (LAI) values for different sites are relatively close. de Moura [32] found $5.6 \mathrm{~m}^{2} \mathrm{~m}^{-2}$ LAI value for Rebio-Jarú, and for the K34 site, Filho et al. [33], using incident solar radiation measurements, estimated LAI at $6.1 \mathrm{~m}^{2} \mathrm{~m}^{-2}$, and Tóta et al. [27] measured $7.3 \mathrm{~m}^{2} \mathrm{~m}^{-2}$ using a LIDAR. At the 


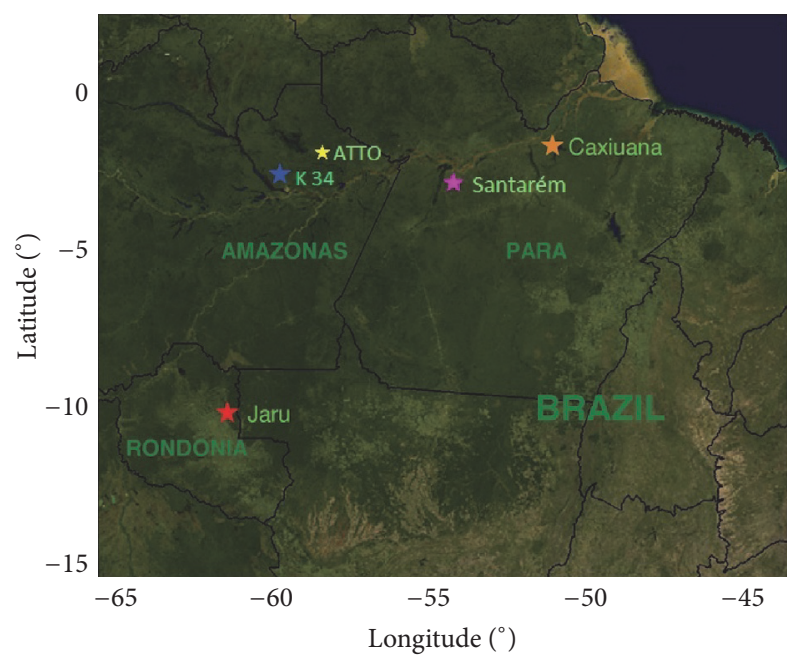

FIGURE 1: Experimental sites located in the Amazon (source: adapted from Zeri et al. [26]).

Santarém site, Asner et al. [34] found LAI to be approximately $6.3 \mathrm{~m}^{2} \mathrm{~m}^{-2}$ in October (dry season) and $5.8 \mathrm{~m}^{2} \mathrm{~m}^{-2}$ for January (rainy season). In Caxiuanã, seasonal variation of LAI is quite sharp, reaching a peak in October, larger than $6 \mathrm{~m}^{2} \mathrm{~m}^{-2}$ [31]. Preliminary measures made in September 2013 at the ATTO site indicate LAI of 5.7 \pm 0.37 (Giordane Martins, personal communication, November, 2016).

2.2. Methodology. To obtain the vertical wind speed profiles, averages of the entire time period for which data were available were taken for each height in each experimental site (Table 1). Data from three-dimensional sonic anemometers were used with the following to calculate the wind speed $U$ :

$$
U=\sqrt{\left(u^{2}+v^{2}\right)}
$$

where $u$ and $v$ are zonal and meridional wind velocity components, respectively.

In this work, we use two models to simulate the vertical wind profile above and below the forest canopy. The first, which will be called Yi Model $[13,36]$, describes the profile:

$$
\bar{u}(z)=\bar{u}_{h}\left[\frac{c_{D}^{h}}{c_{D}(z)}\right] \exp \{-0,5[\mathrm{LAI}-L(z)]\},
$$

where $\bar{u}_{h}$ is the average wind speed at $h$ height $(h=35 \mathrm{~m}$ is the average canopy height), $c_{D}(z)$ is the drag coefficient at $z$ height, $c_{D}^{h}=c_{D}(h)$; LAI is the leaf area index; and $L(z)$ is the cumulative leaf area index, defined as

$$
L(z)=\int_{0}^{z} \alpha\left(z^{\prime}\right) d z^{\prime}
$$

where $\alpha$ is the leaf area density.

The leaf area density was assumed from the values obtained by Tóta et al. [27] at the tower K34 site (Figure 2). The drag coefficient was calculated as $[10,37]$

$$
c_{D}(z)=\frac{u_{*}^{2}(z)}{U^{2}(z)},
$$

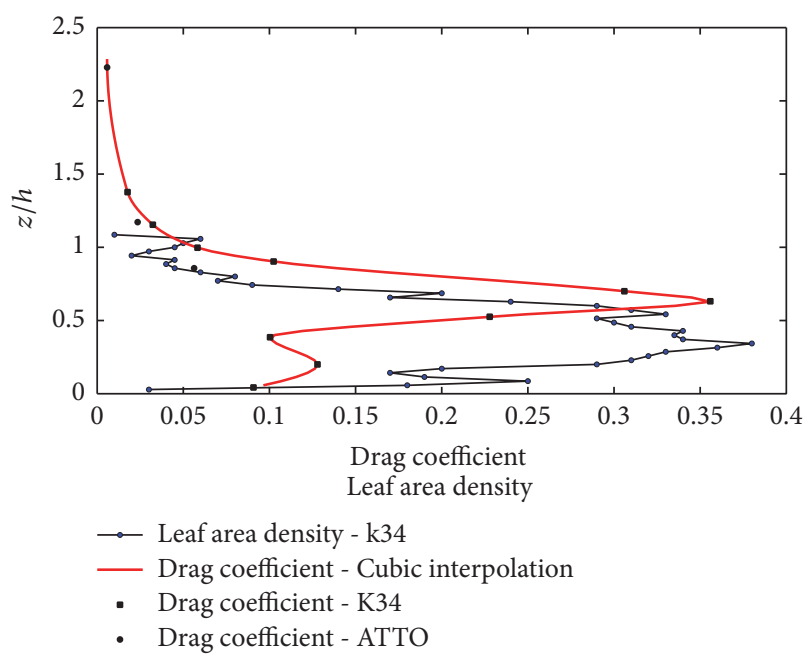

FIGURE 2: Leaf area density vertical profile (source: Tóta et al. [27]) and drag coefficient profile.

where $u_{*}=\left[\left(\overline{u^{\prime} w^{\prime}}\right)^{2}+\left(\overline{v^{\prime} w^{\prime}}\right)^{2}\right]^{1 / 4}$ is the friction velocity wherein $u^{\prime}, v^{\prime}$, and $w^{\prime}$ are the wind turbulent components. This equation was applied to each height for both K34 and ATTO-TT. We then used the cubic interpolation technique to obtain values at other heights in the vertical profile (Figure 2).

The second model used in this study is an empiricalanalytical model based on data from sites in the Amazon and mathematical function properties, developed by Souza et al. [24] (called the Souza Model from this point forward), given by the equation:

$$
\begin{aligned}
& \bar{u}(z)=\bar{u}_{h}\left\{\left[\frac{-1+\exp (\mu z)}{\exp (\omega z)}\right] \alpha\right. \\
& \left.\cdot \tanh \left[\beta+\gamma \exp \left(-\operatorname{LAI}\left(1-\frac{z}{z_{\text {ip }}}\right)\right)\right]\right\},
\end{aligned}
$$

where $\mu, \omega, \alpha, \beta$, and $\gamma$ are fit parameters of the equation to the observed data, $z$ is the height, and $z_{\text {ip }}$ is the inflection point height in the vertical wind profile. This model used a larger number of fit parameters, a fact that will be further discussed in the next section.

\section{Results and Discussion}

Figure 3 shows the vertical profile of the wind velocity of the K34 and ATTO triangular tower for the daytime (Figure 3(a)) and nighttime (Figure 3(b)) periods. Such profiles are complementary: whereas the K34 measurements show wind speed behavior inside the canopy, the ATTO data provides more information above the canopy. The shape of the profiles does not change significantly between the daytime and nighttime periods, but in general the speeds recorded during the day, at each height, showed slightly higher values than the nighttime. Due to the vegetation structure below $0.8 \mathrm{~h}$ wind speed showed very low values, lower than $0.25 \mathrm{~ms}^{-1}$, except for at $0.65 h$ in the daytime ATTO profile. This point, in turn, showed the maximum 


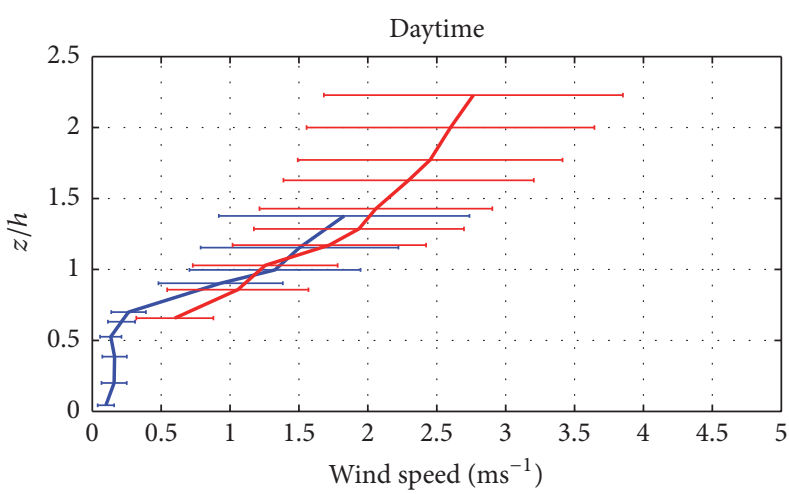

The standard deviation is shown as error bars - K34
- ATTO-TT

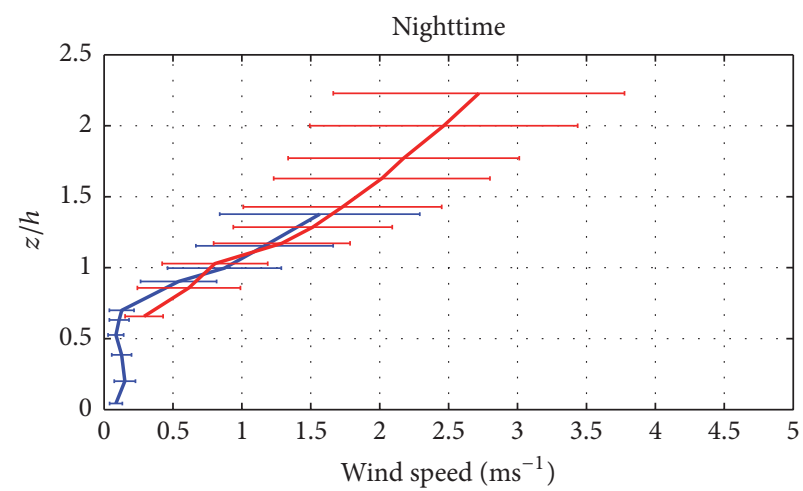

The standard deviation is shown as error bars

- K34

— ATTO-TT

(a)

(b)

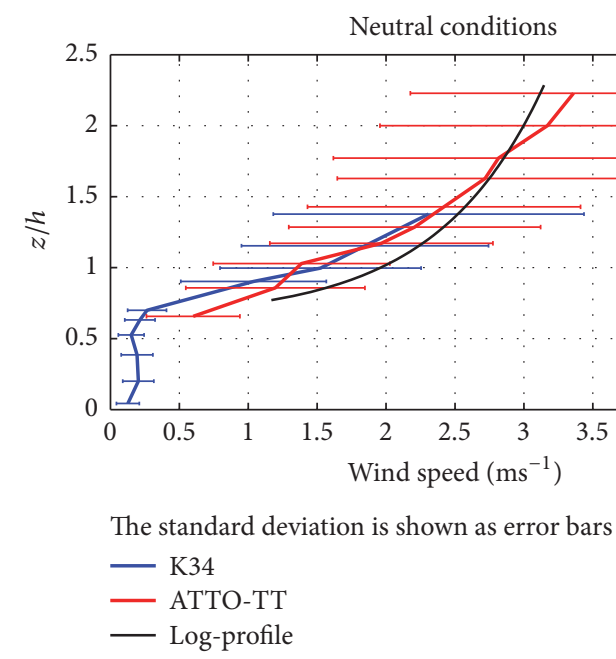

(c)

FIGURE 3: Vertical wind profile for K34 (blue line) and ATTO triangular tower (red line). The horizontal lines represent the standard deviation for each measurement point. The logarithmic profile was obtained through the equation $\bar{u}=\left(u_{*} / k\right) \ln \left((z-d) / z_{0}\right)$, where $k$ is von Karman's constant, $z_{0}=(1 / 30) h$ is roughness length, and $d=0.75 h$ is displacement height [17].

difference between the profiles observed for an equivalent height, probably caused by differences in the vegetation structure between the sites.

The atmospheric stability was close to neutral, and the vertical wind profile above the forest canopy is assumed to be the theoretical logarithmic profile [17]. This assumption is approximate for both K34 and ATTO-TT sites, and Figure 3(c) shows the comparison between said logarithmic profile and the observed data. In this analysis, it is possible to note that from $0.7 h$ to $1.5 h$ the theoretical logarithmic profile overestimates the measured wind speed values; on the other hand, above $1.7 h$ the values observed for the ATTO-TT were slightly higher than said logarithm profile. The reason for these differences is the roughness sublayer just above the forest canopy, and this complicates the effort to estimate accurately the relationship between the mean turbulent variables and the canopy structure [38].

From the K34 and ATTO-TT data, we obtained the fitting constants required for the Souza Model, using the least squares technique (Table 2). The constants were obtained in
TABLE 2: Souza Models fit constants.

\begin{tabular}{lcc}
\hline Constants & Souza Model & Modified Souza Model \\
\hline$\mu$ & 1.016 & 1.012 \\
$\beta$ & 0.1583 & 0.1 \\
$\alpha$ & 0.7275 & - \\
$\omega$ & 1 & - \\
$\gamma$ & 1.973 & - \\
\hline
\end{tabular}

two ways: first by using the original equation proposed by de Souza et al. [24] (5) in which five constants are required; in the second case, we used a formulation proposed here, where only two constants are used.

$$
\begin{aligned}
& \bar{u}(z)=\bar{u}_{h}\left\{\left[\frac{-1+\exp (\mu z)}{\exp (z)}\right]\right. \\
& \left.\cdot \tanh \left[\beta+\exp \left(-\operatorname{LAI}\left(1-\frac{z}{z_{\text {ip }}}\right)\right)\right]\right\} .
\end{aligned}
$$




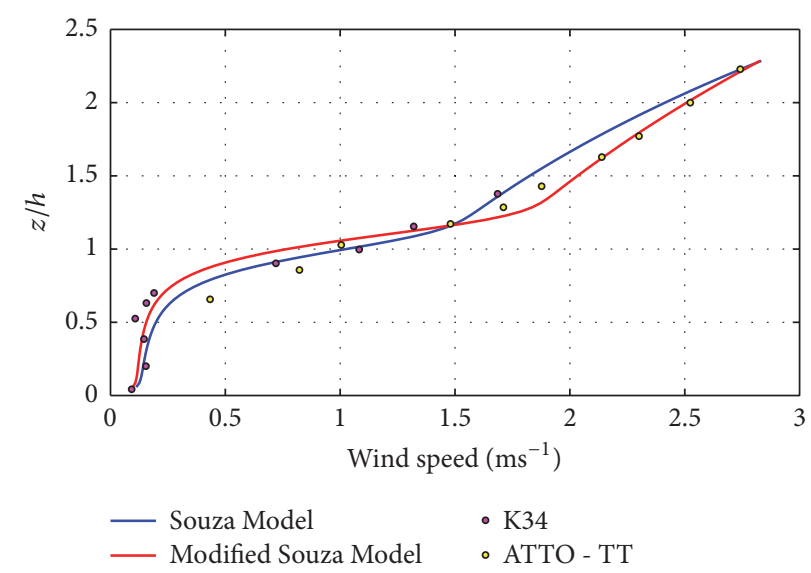

FIGURE 4: Observed and modeled vertical wind profiles.

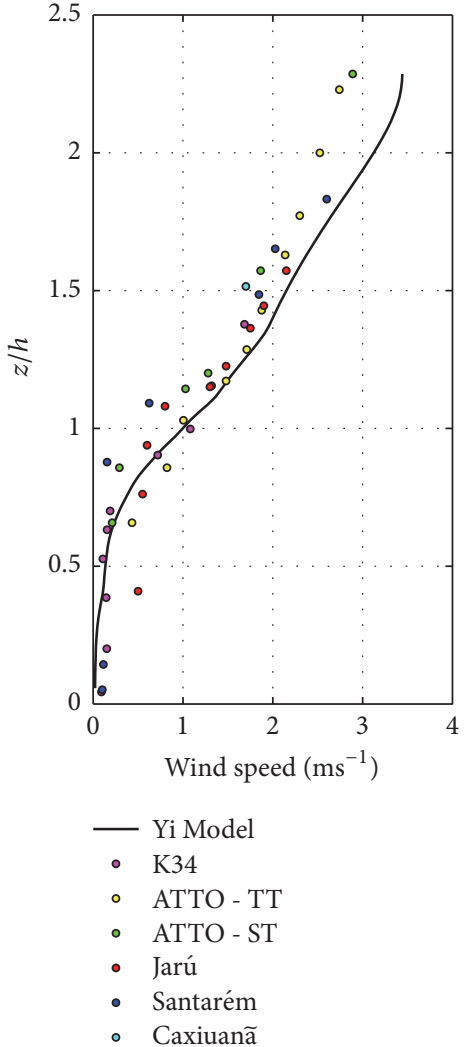

(a)

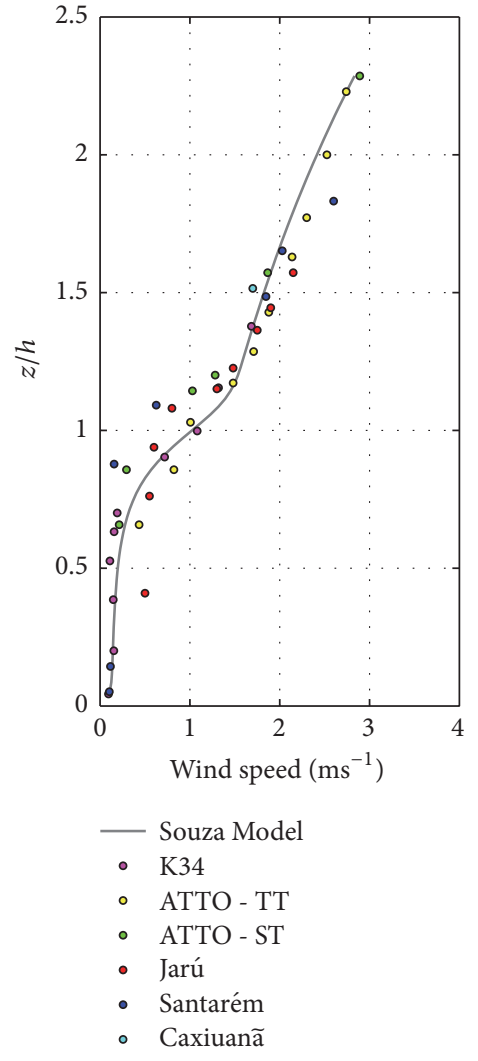

(b)

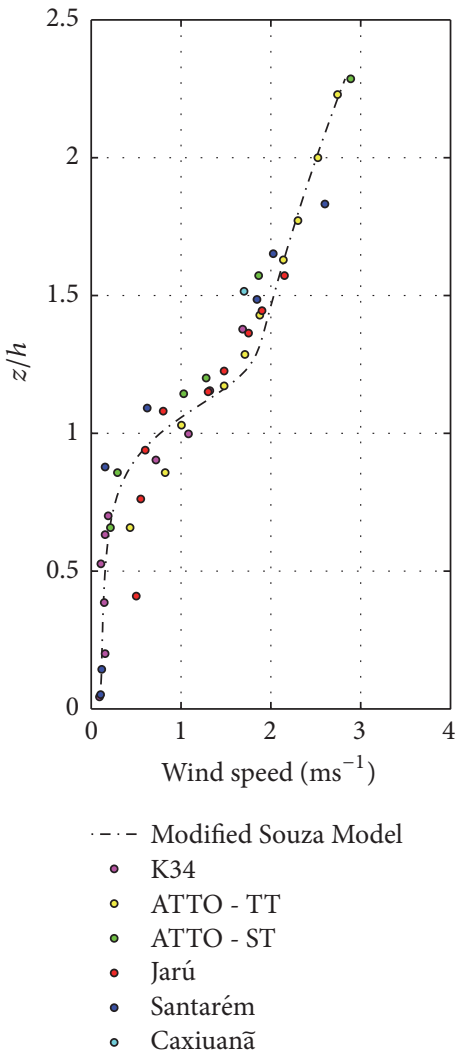

(c)

FIGURE 5: Vertical wind profile observed and modeled in different experimental sites in the Amazon.

For both (5) and (6), the Souza Model fits very well to the K34 and ATTO-TT data, with a coefficient of determination $\left(r^{2}\right)$ of 0.98 and 0.97 , respectively (Figure 4). Thus, (6) is more advantageous because it has a smaller number of necessary constants for the mathematical fit (the model of (6) will be called Modified Souza Model from this point forward).

An important question is whether the Souza Models (original and modified), which fit the K34 and ATTO-TT data very well, can be used to represent the vertical wind profile for other experimental sites in the Amazon. Also, a good test to see if the model represents such profiles is to compare their performance with that of another model that has already been tested in other conditions, such as the Yi Model.

We can conclude from this analysis that all models represented fairly well the vertical profile of the wind velocity for different Amazonian experimental sites (Figure 5), although there are differences among both the models and simulated and observed wind speed values, to a greater or lesser degree, for some heights. In Figures 6(a), 6(b), and 6(c), the observed wind speed values were plotted against the model output 


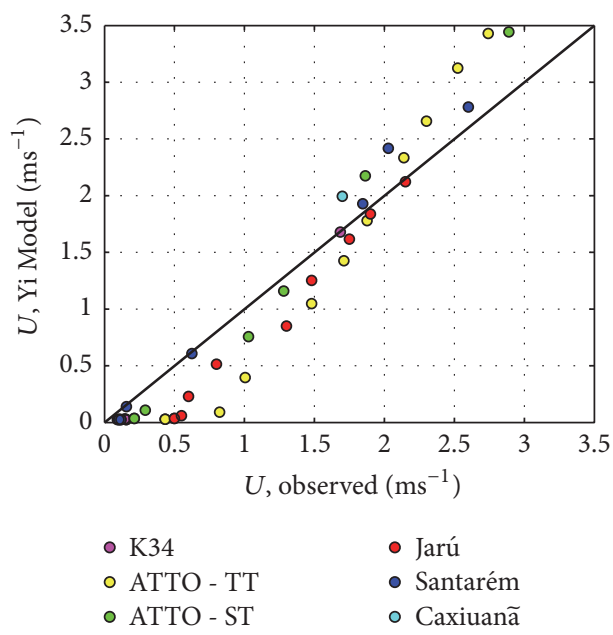

(a)

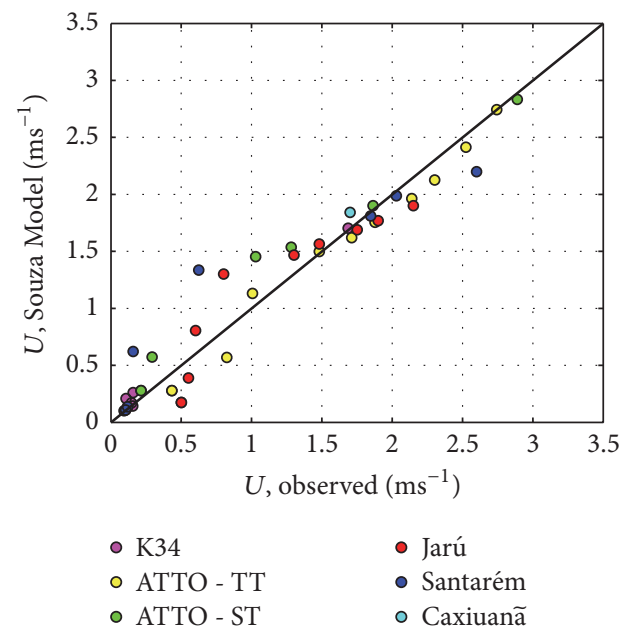

(b)

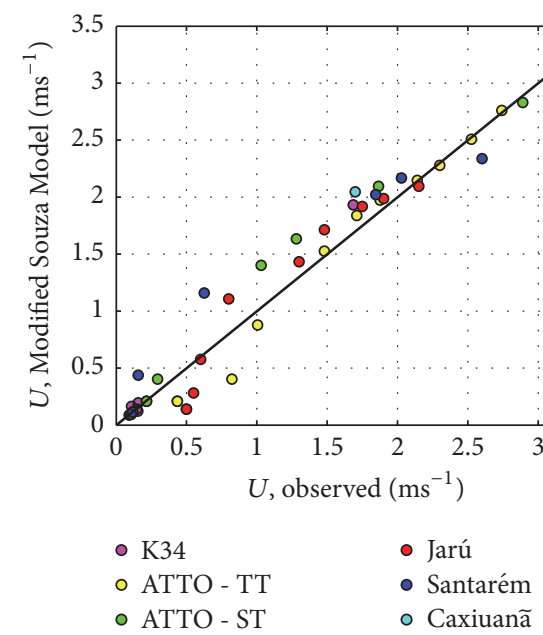

(c)

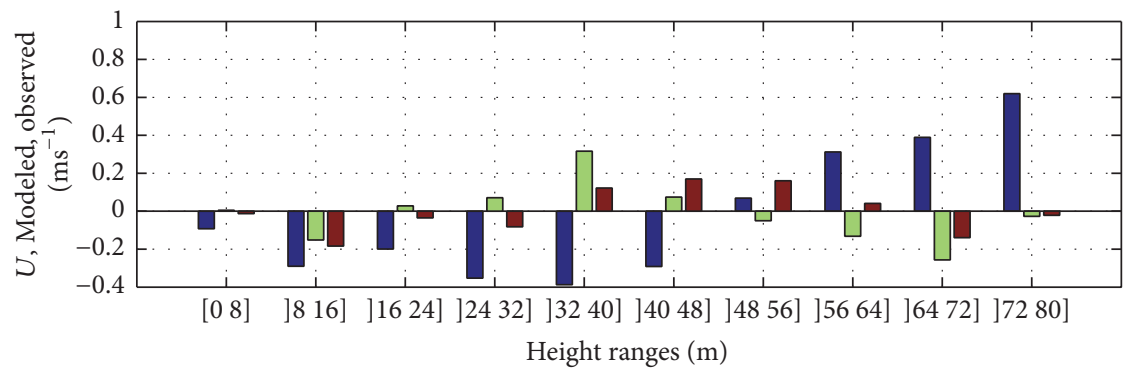

Yi Model

$\square$ Souza Model

- Modified Souza Model

(d)

Figure 6: Wind speed $(U)$ observed versus modeled for the three models used in this study ((a), (b), and (c)). Part (d) shows the modeled minus observed wind speed for different intervals of heights, above and below the forest canopy.

to measure the degree to which data points approach the line with an $45^{\circ}$ angular coefficient, and which model better represents the observations at each point. Among the models, the Yi Model was the one that presented, on average, the greatest distance of observed values. The two versions of the Souza Models have similar behavior, but the Modified Souza Model has a slightly higher coefficient of correlation (0.973) compared to the original Souza Model (0.967). 
To verify the ability of each model at different heights, an average of the observed and simulated wind speed values was calculated at intervals of 8 meters in height and then the difference between the modeled and observed values was calculated (Figure 6(d)). The results show that the Yi Model overestimated the wind velocity values above $48 \mathrm{~m}$ in height, with a greater difference between 72 and $80 \mathrm{~m}$, while at the same time it underestimated values below $48 \mathrm{~m}$, with a meansquared error (MSE) of $0.12 \mathrm{~ms}^{-1}$. The Souza Model had its maximum divergence between 32 and $40 \mathrm{~m}$, with a difference of $0.3 \mathrm{~ms}^{-1}$ between the modeled value and the observed value. The Modified Souza Model was the one that presented the smallest absolute value at its point of maximum difference between the heights of 8 and $16 \mathrm{~m}$ and also presented the lowest MSE, $0.04 \mathrm{~ms}^{-1}$. Again, this shows that a smaller number of fit parameters in the Souza Model do not change the model's ability to simulate the vertical wind profile for different sites in the Amazon.

Each of the three models has satisfactory performance; using one or the other model depends on each situation. In the Souza Model, the constants must be different for other forest types, after which calculations for a given profile may be extrapolated to others with similar vegetation structure. Since the Yi Model requires, in addition to other input variables, the profile drag coefficient, this, in turn, needs to be calculated for the type of vegetation.

\section{Conclusions}

In this work, we examined the vertical wind profile measured at different experimental sites in Amazonia. Measurements with high resolution below the canopy, performed at the K34 site, and above the canopy at the ATTO triangular tower represent for the first time that such data have been compiled in a single work and have provided a broader view of the wind vertical profile behavior in the Amazon forest. Under the forest canopy, the wind speed values were very low due to the vegetation structure, while above the canopy wind increases with height in an approximately logarithmic behavior. Furthermore, with data from the two sites mentioned above, it was possible to obtain a new formulation for the Souza Model, with a reduced number of input variables, which facilitates the use of the model for future applications. Both Souza Models (original and modified) and the Yi Model managed to satisfactorily represent the vertical wind profile for different sites in the Amazon.

\section{Competing Interests}

The authors declare that they have no competing interests.

\section{Acknowledgments}

The authors acknowledge the funding provided by the Coordination of Higher Education and Personnel Training (CAPES) and all who participated in the GoAmazon project at K34 and ATTO IOP-1-2012 for the excellent quality of the collected data.

\section{References}

[1] M. A. F. Silva Dias, S. Rutledge, P. Kabat et al., "Cloud and rain processes in a biosphere-atmosphere interaction context in the Amazon Region," Journal of Geophysical Research D: Atmospheres, vol. 107, no. 20, pp. LBA 39-1-LBA 39-18, 2002.

[2] M. O. Andreae, D. Rosenfeld, P. Artaxo et al., "Smoking rain clouds over the amazon," Science, vol. 303, no. 5662, pp. 13371342, 2004.

[3] M. O. Andreae, O. C. Acevedo, A. Araùjo et al., "The Amazon Tall Tower Observatory (ATTO): overview of pilot measurements on ecosystem ecology, meteorology, trace gases, and aerosols," Atmospheric Chemistry and Physics, vol. 15, no. 18, pp. 10723-10776, 2015.

[4] J. D. Fuentes, M. Chamecki, R. M. Nascimento dos Santos et al., "Linking meteorology, turbulence, and air chemistry in the Amazon rainforest," Bulletin of the American Meteorological Society, 2016.

[5] C. von Randow, A. O. Manzi, B. Kruijt et al., "Comparative measurements and seasonal variations in energy and carbon exchange over forest and pasture in South West Amazonia," Theoretical and Applied Climatology, vol. 78, no. 1-3, pp. 5-26, 2004.

[6] J. Wang, R. Krejci, S. Giangrande et al., "Amazon boundary layer aerosol concentration sustained by vertical transport during rainfall," Nature, vol. 539, no. 7629, pp. 416-419, 2016.

[7] T. Gerken, D. Wei, R. J. Chase et al., "Downward transport of ozone rich air and implications for atmospheric chemistry in the Amazon rainforest," Atmospheric Environment, vol. 124, pp. 64-76, 2016.

[8] J. H. C. Gash and C. A. Nobre, "Climatic effects of amazonian deforestation: some results from ABRACOS," Bulletin of the American Meteorological Society, vol. 78, no. 5, pp. 823-830, 1997.

[9] W. J. Shuttleworth, "Observations of radiation exchange above and below Amazonian forest," Quarterly Journal of the Royal Meteorological Society, vol. 110, no. 466, pp. 1163-1169, 1984.

[10] D. R. Fitzjarrald, B. L. Stormwind, G. Fisch, and O. M. R. Cabral, "Turbulent transport observed just above the Amazon forest," Journal of Geophysical Research, vol. 93, no. 2, pp. 1551-1563, 1988.

[11] B. Kruijt, Y. Malhi, J. Lloyd et al., "Turbulence statistics above and within two Amazon rain forest canopies," Boundary-Layer Meteorology, vol. 94, no. 2, pp. 297-331, 2000.

[12] D. M. Santos, O. C. Acevedo, M. Chamecki, J. D. Fuentes, T. Gerken, and P. C. Stoy, "Temporal scales of the nocturnal flow within and above a forest canopy in Amazonia," BoundaryLayer Meteorology, vol. 161, no. 1, pp. 73-98, 2016.

[13] C. Yi, "Momentum transfer within canopies," Journal of Applied Meteorology and Climatology, vol. 47, no. 1, pp. 262-275, 2008.

[14] D. R. Fitzjarrald, K. E. Moore, O. M. R. Cabral, J. Scolar, A. O. Manzi, and L. D. de Abreu Sá, "Daytime turbulent exchange between the Amazon forest and the atmosphere," Journal of Geophysical Research: Atmospheres, vol. 95, no. 10, pp. 16-838, 1990.

[15] D. R. Fitzjarrald and K. E. Moore, "Mechanisms of nocturnal exchange between the rain forest and the atmosphere," Journal of Geophysical Research, vol. 95, no. 10, pp. 16839-16850, 1990.

[16] C. Q. Dias-Júnior, L. D. Sá, E. P. Marques Filho, R. A. Santana, M. Mauder, and A. O. Manzi, "Turbulence regimes in the stable boundary layer above and within the Amazon forest," Agricultural and Forest Meteorology, vol. 233, pp. 122-132, 2017. 
[17] J. C. Kaimal and J. J. Finnigan, Atmospheric Boundary Layer Flows-Their Structureand Measurement, 1994.

[18] P. Cellier and Y. Brunet, "Flux-gradient relationships above tall plant canopies," Agricultural and Forest Meteorology, vol. 58, no. 1-2, pp. 93-117, 1992.

[19] M. R. Raupach, J. J. Finnigan, and Y. Brunet, "Coherent eddies and turbulence in vegetation canopies: the mixing-layer analogy," Boundary-Layer Meteorology, vol. 78, no. 3-4, pp. 351382, 1996.

[20] J. Finnigan, “Turbulence in plant canopies," Annual Review of Fluid Mechanics, vol. 32, pp. 519-571, 2000.

[21] C.-H. Lu and D. R. Fitzjarrald, "Seasonal and diurnal variations of coherent structures over a deciduous forest," Boundary-Layer Meteorology, vol. 69, no. 1-2, pp. 43-69, 1994.

[22] C. Q. Dias Júnior, L. D. A. Sá, V. B. Pachêco, and C. M. de Souza, "Coherent structures detected in the unstable atmospheric surface layer above the Amazon forest," Journal of Wind Engineering and Industrial Aerodynamics, vol. 115, pp. 1-8, 2013.

[23] L. D. A. Sá and V. B. Pachêco, "Relações de similaridade para os perfis de velocidade média do vento dentro da copa da floresta amazônica em Rondônia," Revista Brasileira de Meteorologia, vol. 16, no. 1, pp. 81-89, 2001.

[24] C. M. de Souza, C. Q. Dias-Júnior, J. Tóta, and L. D. de Abreu Sá, "An empirical-analytical model of the vertical wind speed profile above and within an Amazon forest site," Meteorological Applications, vol. 23, no. 1, pp. 158-164, 2016.

[25] L. D. D. A. Sá and V. B. Pachêco, "Wind velocity above and insi amazonian rain forest in Rondônia," Revista Brasileira de Meteorologia, vol. 21, no. 3, pp. 50-58, 2006.

[26] M. Zeri, L. D. A. Sá, and C. A. Nobre, "Contribution of coherent structures to the buoyancy heat flux under different conditions of stationarity over Amazonian forest sites," Atmospheric Science Letters, vol. 16, no. 3, pp. 228-233, 2015.

[27] J. Tóta, D. Roy Fitzjarrald, and M. A. F. Da Silva Dias, "Amazon rainforest exchange of carbon and subcanopy air flow: manaus LBA Site-a complex terrain condition," The Scientific World Journal, vol. 2012, Article ID 165067, 19 pages, 2012.

[28] M. O. Andreae, P. Artaxo, C. Brandão et al., "Biogeochemical cycling of carbon, water, energy, trace gases, and aerosols in Amazonia: The LBA-EUSTACH experiments," Journal of Geophysical Research D: Atmospheres, vol. 107, no. 20, pp. LBA 33-1-LBA 33-25, 2002.

[29] A. C. Araújo, "Comparative measurements of carbon dioxide fluxes from two nearby towers in a central Amazonian rainforest: the Manaus LBA site," Journal of Geophysical Research, vol. 107, no. D20, pp. 1-20, 2002.

[30] J. Tóta, D. R. Fitzjarrald, R. M. Staebler et al., "Amazon rain forest subcanopy flow and the carbon budget: Santarém LBAECO site," Journal of Geophysical Research: Biogeosciences, vol. 114, no. 1, Article ID G00B02, pp. 1-15, 2008.

[31] F. E. Carswell, A. L. Costa, M. Palheta et al., "Seasonality in $\mathrm{CO}_{2}$ and $\mathrm{H}_{2} \mathrm{O}$ flux at an eastern Amazonian rain forest," Journal of Geophysical Research D: Atmospheres, vol. 107, no. 20, pp. LBA 43-1-LBA 43-16, 2002.

[32] R. G. de Moura, Estudos das Radiações Solar e Terrestre Acima e Dentro de Uma Floresta Tropical Úmida, 2001.

[33] A. D. M. Filho, R. G. Dallarosa, and V. B. Pachêco, "Radiação solar e distribuição vertical de área foliar em floresta-Reserva Biológica do Cuieiras ZF2, Manaus," Acta Amazonica, vol. 35, no. 4, pp. 427-436, 2005.
[34] G. P. Asner, D. Nepstad, G. Cardinot, and D. Ray, "Drought stress and carbon uptake in an Amazon forest measured with spaceborne imaging spectroscopy," Proceedings of the National Academy of Sciences of the United States of America, vol. 101, no. 16, pp. 6039-6044, 2004.

[35] L. Newton, "Sobre as características de formação de estrutura coerente e turbulência em uma floresta densa de terra firme com medidas em até 80m de altura: Projeto ATTO-CLAIRE / IOP1-2012," 2014.

[36] C. Yi, R. K. Monson, Z. Zhai et al., "Modeling and measuring the nocturnal drainage flow in a high-elevation, subalpine forest with complex terrain," Journal of Geophysical Research Atmospheres, vol. 110, no. 22, pp. 1-13, 2005.

[37] L. Mahrt, X. Lee, A. Black, H. Neumann, and R. M. Staebler, "Nocturnal mixing in a forest subcanopy," Agricultural and Forest Meteorology, vol. 101, no. 1, pp. 67-78, 2000.

[38] R. K. Sakai, D. R. Fitzjarrald, and K. E. Moore, "Importance of low-frequency contributions to eddy fluxes observed over rough surfaces," Journal of Applied Meteorology, vol. 40, no. 12, pp. $2178-2192,2001$. 

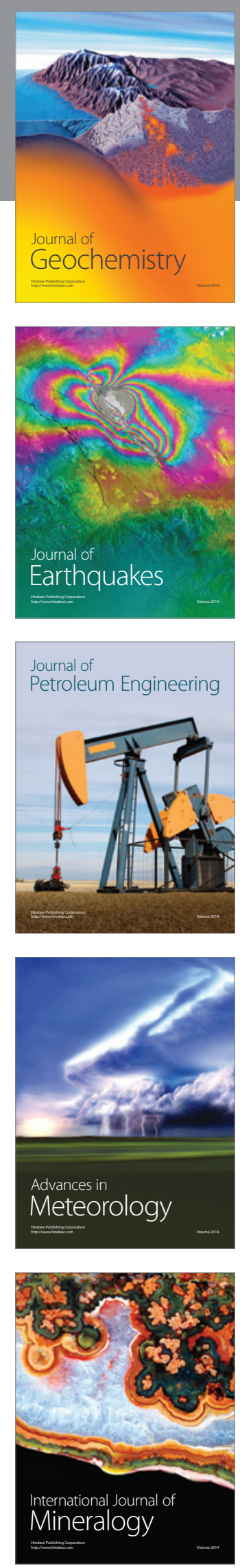
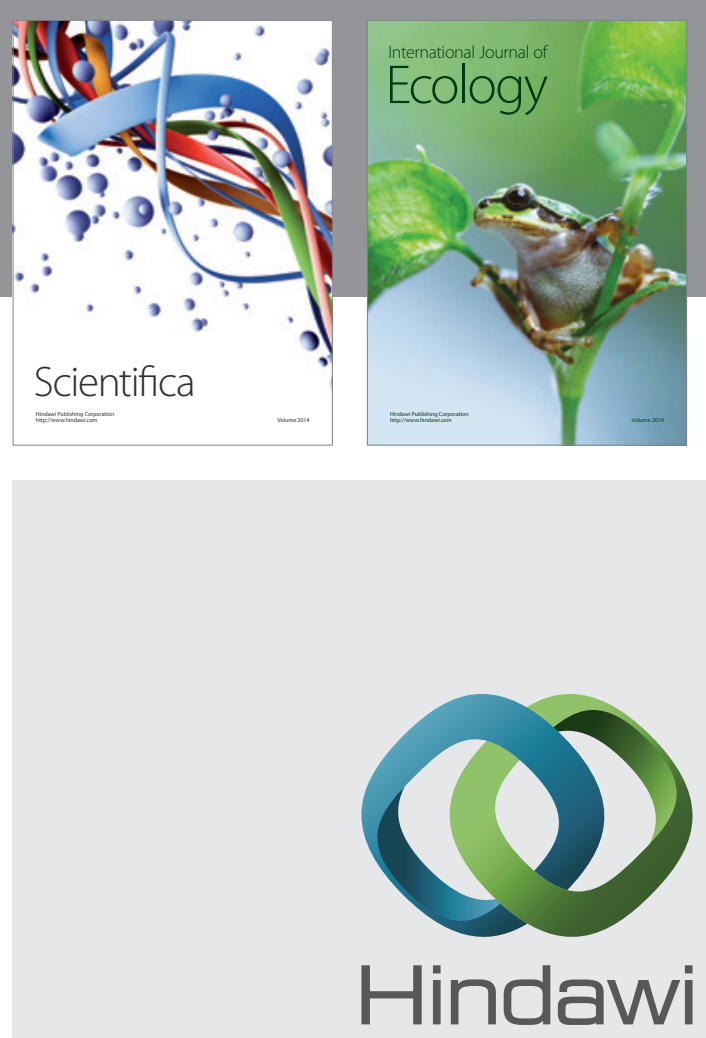

Submit your manuscripts at

https://www.hindawi.com
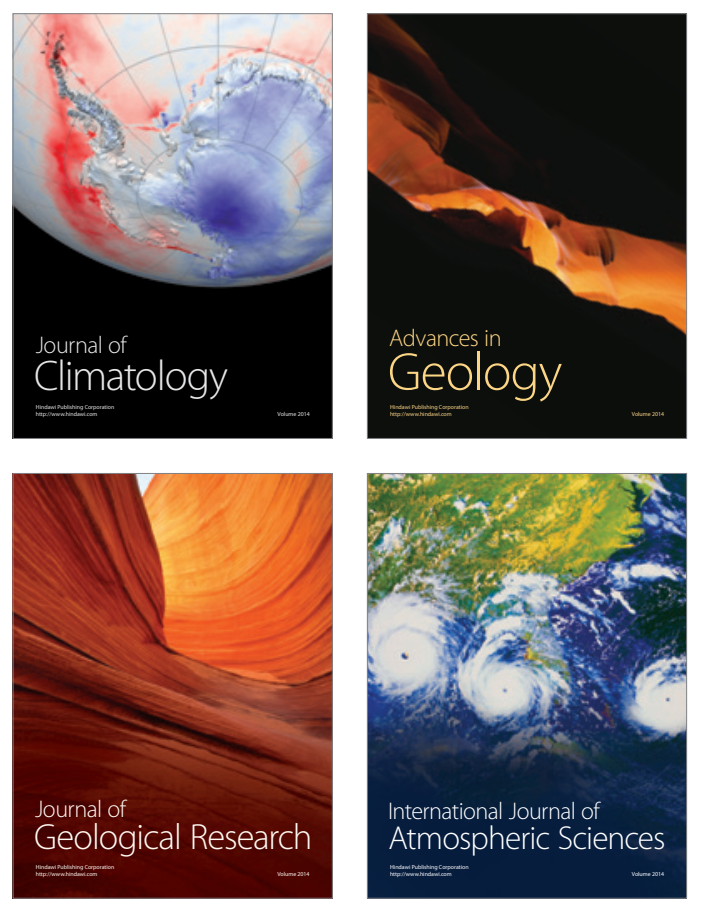

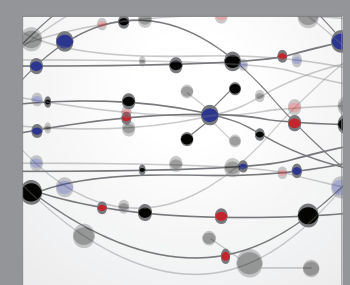

The Scientific

\section{World Journal}
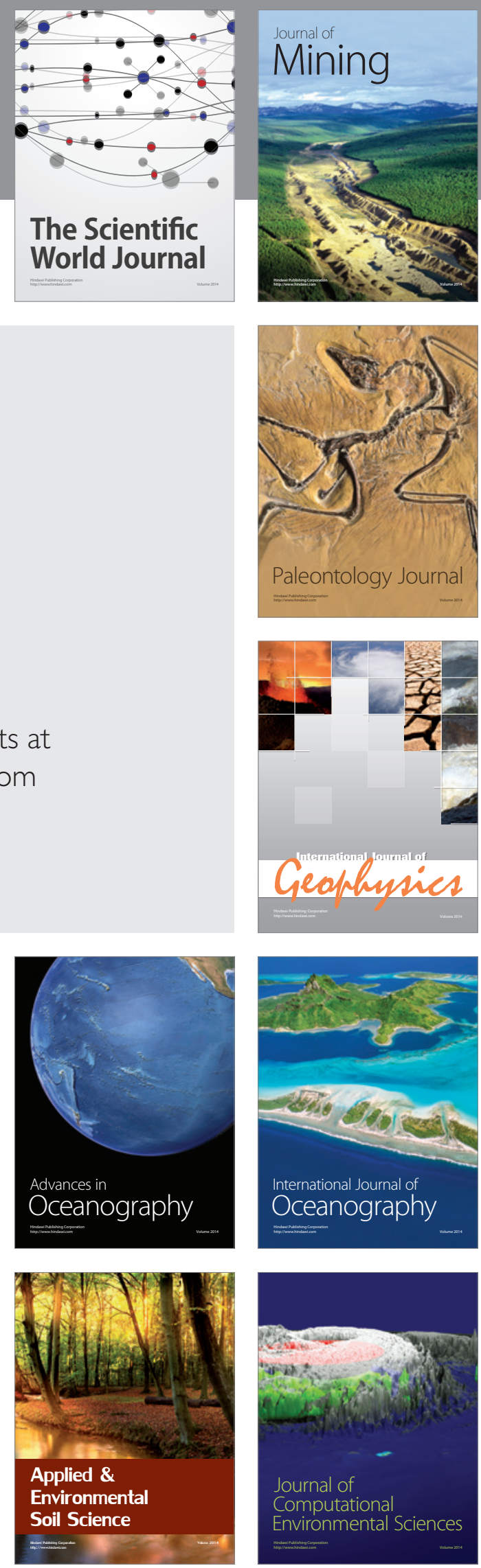